\title{
MARX, MÍDIA E EDUCAÇÃO NO BRASIL: UM INTRICADO PROCESSO
}

Sidnei Ferreira de Vares*

Resumo: Este artigo tem por intuito discutir as relações entre Marx, mídia e educação no Brasil, a partir da análise de algumas narrativas contrárias ao pensamento do filósofo alemão que, nos últimos anos, se intensificaram nas mídias tradicional e alternativa, e que coincidiram com o surgimento do movimento Escola Sem Partido, cujo principal alvo são os professores de humanidades, acusados por seus integrantes de realizar proselitismo ideológico em sala de aula, na condição de agentes do "marxismo cultural". $\mathrm{Na}$ medida do possível, procuramos mostrar as afinidades entre os difusores destas distorções através da mídia e os princípios que, desde o primeiro instante, deram forma a esse movimento. Ao mesmo tempo procura-se revelar a fragilidade dessas análises e princípios, buscando no legado marxista elementos críticos que possibilitem maior clareza acerca deste processo.

Palavras-chave: mídia, educação, Escola Sem Partido, marxismo cultural, esquerda.

\section{INTRODUÇÃO}

As sociedades capitalistas sempre podem dar um suspiro de alívio dizendo-se: o comunismo acabou desde os desmoronamentos dos totalitarismos do século XX, e não somente acabou com também aconteceu, isso não passou de um fantasma. Mal podem denegar isto, o inegável mesmo: um fantasma não morre nunca, está sempre por vir ou por retornar

(DERRIDA, 1994, p. 57-58).

A figura de Karl Marx (1818-1883) nunca foi muito bem aceita entre os membros das elites econômicas e políticas contemporâneas. Afinal, o filósofo alemão não só analisou e tentou compreender a dinâmica do modo de produção capitalista, mas também ousou destruí-la e superá-la em nome de uma organização societária futura, caracterizada pela socialização dos meios de produção e a planificação econômica (o comunismo), que na visão do "mouro"1 inauguraria uma nova fase na trajetória humana ou seja, a passagem da pré-história à história propriamente dita. Como salienta Jorge Grespan (2021, p. 10-12), o objetivo de Marx consistiu em: “desmascarar a pretensa normalidade de que se revestem até mesmo os fenômenos mais insuspeitos e contraditórios da sociedade moderna. Além de descritiva e explicativa, sua obra é uma teoria crítica do capitalismo que revela a contradição profunda na base desse sistema".

Decerto, Marx foi um intelectual militante, que sempre expôs publicamente suas posições sem fugir de polêmicas, muitas vezes de maneira ácida em relação a seus adversários políticos e detratores ou

\footnotetext{
* Doutor e mestre em Educação pela USP. Professor da Universidade São Judas - USTJ e do Centro Universitário Assunção - UNIFAI.

1 Apelido de Marx, comumente utilizado pelos membros de seu círculo de convivência, inclusive por sua esposa, Jenny Von Westphalen, e por seu grande parceiro intelectual, Friedrich Engels, devido a seus traços fisionômicos.
} 
se posicionando firmemente contra qualquer tipo de ideologização no campo das ideias, sobretudo aquelas que, aparentemente sólidas, "desmancham no ar" no confronto com a realidade concreta, isto é, com a história.

No Brasil, as coisas não são diferentes. As elites brasileiras sempre se revelaram refratárias e hostis às ideias marxianas. Aqui, a penetração das ideias marxianas, entre o final do século XIX e as primeiras décadas do século $\mathrm{XX}^{2}$, também despertou paixões diversas, a favor ou contra, conquanto, entre os detentores do capital, e mesmo entre parcela dos estratos sociais médios, a impressão acerca de sua influência seja predominantemente negativa, identificando-a com as mazelas dos regimes socialistas historicamente constituídos.

Os motivos desta ojeriza são variados. Em primeiro lugar, durante décadas os regimes socialistas foram "demonizados". A guerra-fria e a influência estadunidense sobre o Ocidente, e em especial na América Latina, concorreram para que Marx e o comunismo por ele propugnado se convertessem em uma ameaça ao liberalismo deformado que emoldurou a social brasileira a partir do século XIX. Em segundo lugar, cumpre destacar o papel exercido num passado recente pela Igreja Católica, e atualmente pelas Igrejas neopentecostais ${ }^{3}$, que vêm no marxismo a negação das tradições religiosas e dos valores cristãos que, por certo, também contribuíram para nossa formação histórica e social. Por último, podese apontar o papel da mídia tradicional, porta-voz de uma visão liberal-conservadora, mas também de parte da mídia alternativa, na desconstrução imagética do comunismo, bem como na difusão de todo o tipo de distorções sobre o assunto, que certamente incidem sobre o imaginário popular.

Claro, há outros motivos além destes. Mas o fato é que esta “demonização" tem se espraiado por outros campos sociais como, por exemplo, o da educação. Falar de Marx em sala de aula tornou-se um desafio, muitas vezes desgastante para parcela dos professores da área das Ciências Humanas, ou seja, aqueles que se dedicam ao ensino da História, Geografia, Sociologia e Filosofia, devido à polarização política que acometeu o país nos últimos anos. ${ }^{4}$ Isso porque, em algumas situações, por vezes pontuais,

\footnotetext{
${ }^{2}$ No dia $1^{\circ}$ de Julho de 1892 ocorreu, no Rio de Janeiro, o I Congresso Socialista Brasileiro, organizado por Luiz França e Silva, editor do jornal Echo Popular, que reuniu 400 operários oriundos de várias partes do país. O objetivo do Congresso, que era discutir as ideias socialistas no Brasil, resultou na fundação, em Janeiro de 1893, na fundação do Partido Socialista Brasileiro. Todavia, o novo partido durou poucos meses, dissolvendo-se naquele mesmo ano, após a morte de França e Silva. (AQUINO, 2007, p. 91-93). Em 25 de março de 1922, todavia, é fundado o Partido Comunista do Brasil (PCB), influenciado pelo sucesso da Revolução Russa, de 1917, a partir de alguns membros dissidentes do movimento anarquista. Mais tarde, o PCB se tornará uma seção da Internacional Comunista, sendo perseguido em inúmeras ocasiões, como durante o Estado Novo e, após a redemocratização de 1946 e a ditadura civil-militar, entre 1964 e 1985 (FAUSTO, 2012, p. 303-305). Estas, sem dúvida, foram as experiências socialistas brasileiras mais antigas em nosso país. Depois delas, outros partidos e agremiações à esquerda surgiram, revelando as diferentes leituras teóricas e conceituais do marxismo acerca da realidade política, econômica e social brasileira.

${ }^{3}$ Faz-se, contudo, questão de salientar que se trata de uma parte das Igrejas Católica e Neopentecostal, com vistas a evitar generalizações, pois existem em ambas as denominações religiosas segmentos que destoam completamente desta visão e adotam uma posição bem mais progressista em relação ao marxismo. Ainda assim, é preciso que se diga, entre os grupos de orientação conservadora destas duas denominações religiosas, as críticas ao marxismo são demasiadamente presentes, e geralmente assentadas em discordâncias quanto ao papel da religiosidade e das instituições religiosas no mundo social, bem como ao ateísmo presente em Marx e na maioria dos que se filiam à essa tradição.

${ }^{4}$ Embora esta polarização seja político-partidária e ideológica, há, sem dúvida, uma propensão em relacionar os partidos de esquerda ao marxismo, em geral, e a Marx, em particular. De modo que não é incomum que parte das críticas à esquerda brasileira respinguem, em alguma medida, na obra do filósofo alemão. Desenvolveremos este assunto no decorrer do texto.
} 
noutras nem tanto, os educandos revelam e reproduzem muitos dos preconceitos que, tanto por meio da influência de seus círculos familiares quanto por meio de outros espaços de convívio social - não só físicos, mas muitas vezes virtuais - absorveram sobre este autor. E, por isso, a sala de aula pode converterse em um espaço de embates acalorados, e não de debates autênticos, muitas vezes caracterizados pela ausência de uma racionalidade que possibilite minimamente um diálogo amistoso, através do qual o esforço do educador em desmistificar estes preconceitos irrompa e transcenda o dogmatismo e a intransigência de alguns de seus jovens interlocutores.

O ponto nevrálgico deste dilema é o seguinte: por que isso ocorre? Em outros termos, por que

9 há tanta desinformação sobre a importância e o alcance do marxismo, e como isso repercute em sala de aula?

Esta é, indubitavelmente, uma questão fundamental e não menos complexa. Poderíamos, certamente, tentar explorar todos os motivos dessas distorções analíticas e interpretativas, acima destacadas, mas, infelizmente, os limites que encerram a extensão deste artigo nos forçam a enfatizar um ponto específico, neste caso o papel da mídia, seja a tradicional ou a chamada mídia alternativa, em suas mais diversas manifestações (escrita, televisiva, radiofônica e virtual), visto que parcela desses jovens alunos se informa por meio destes veículos e, em decorrência, reproduzem com alguma frequência em sala de aula os princípios, majoritariamente depreciativos, contidos nestas narrativas acerca dos pensamento marxista. ${ }^{5}$ Dito de outro modo, como a mídia contribui para distorcer as ideias de Marx? Como essas distorções concorrem para obscurecer as discussões em sala de aula? Eis as questões que visamos responder ao longo deste trabalho.

Para tanto, propomos dividi-lo em três partes. Na primeira parte delas, trabalharemos alguns exemplos, presentes tanto na mídia tradicional quanto na mídia alternativa, das críticas dirigidas ao marxismo. Neste ponto, apresentar-se-á as fontes de onde estas críticas foram extraídas, procurando, assim, revelar sua origem midiática. $\mathrm{Na}$ segunda parte, analisaremos os impactos do movimento conhecido como "Escola Sem Partido", e que trouxe à tona a discussão acerca da influência do "marxismo cultural"6 no campo da educação. Embora seja difícil afirmar que este movimento tenha surgido a partir das críticas midiáticas anteriormente enunciadas, tentar-se-á demonstrar que, entre esses dois momentos, há pelo menos uma série de afinidades ideológicas e valorativas que incidem sobre a vida cotidiana dos professores. Por fim, num exercício imaginativo, mas respaldados por parte do legado teórico marxista, procuraremos responder a essas críticas e, na medida do possível, desconstruí-las. Em tempo, deseja-se alertar o leitor que este não se trata de um trabalho conclusivo, mas tão somente de uma

\footnotetext{
5 Embora entre os especialistas o termo "marxiano" dirija-se aos trabalhos do próprio Marx, enquanto o termo "marxista" seja empregado para referir-se aos trabalhos de seus intérpretes, manteremos a expressão marxista, consagrada sobretudo após a morte de Marx para se referir a ambos, bem como ao termo "marxismo" para nominar tanto a teoria desenvolvida pelo filósofo alemão quanto às intepretações dela decorrentes.

${ }^{6} \mathrm{O}$ termo em questão, que encerra uma série de discussões, grosso modo refere-se à esquerda política, sobretudo identificada à tradição marxista, a qual supostamente aderiu a uma nova estratégia de tomada do poder, deslocando a luta do campo político para o cultural. Falaremos melhor sobre isso no decorrer deste trabalho.
} 
contribuição de caráter reflexivo sobre como certas situações podem dificultar a compreensão de uma obra tão importante quanto a de Marx e de seus legatários.

\section{A MÍDIA TRADICIONAL E ALTERNATIVA NA DESCONSTRUÇÃO DO LEGADO MARXISTA}

A palavra "mídia", do Latim "media", corresponde ao "meio" pelo qual as informações são difundidas no interior de uma sociedade. Sabe-se que, em termos modernos, pelo menos desde a invenção da imprensa pelo alemão Guttemberg, no século XVI, o jornal fora o grande veículo de informação, pelo menos até o início do século XX, quando o rádio emerge como uma inovação. Passadas algumas décadas, em meados dos anos de 1950, a televisão veio a ocupar o protagonismo do rádio e do jornal impresso, sem, entretanto, significar a superação de ambos. Na transição para o século XXI, em virtude dos avanços tecnológicos, a humanidade viu surgir a internet e, a partir disso, a diversificação de redes virtuais que revolucionaram a massificação da informação, dando origem a uma verdadeira "sociedade em rede" (CASTELLS, 2013). De modo que, no início deste novo milênio, há uma pluralidade de meios ou veículos de informação. Redes ou grupos sociais, privados ou públicos (sites, páginas, canais e blogs de todas as formas e tipos), passaram a ocupar, para além dos veículos existentes, espaços cada vez maiores e mais viscerais no contexto do cidadão contemporâneo. Disso, sem dúvida, depreende-se as confusões, não incomuns, entre informações documentadas, fundamentadas ou logicamente organizadas e informações distorcidas ou até mesmo falsas.

Estas distorções, infelizmente, encontram-se em toda a extensão do campo midiático, que, por si mesmo, é muito diversificado. Neste sentido, talvez seja necessário estabelecer uma distinção entre "mídia tradicional" e "mídia alternativa". Geralmente, denomina-se mídia tradicional os principais veículos ou canais de comunicação de um país (emissoras de televisão e rádio, jornais e revistas de grande circulação, bem como sites, canais virtuais e blogs a elas vinculadas), cuja capilarização e alcance foram constituídos em anos de atuação jornalística profissional, seguindo padrões aceitos internacionalmente. Já a chamada mídia alternativa é um fenômeno mais recente, que está diretamente atrelado à democratização informacional decorrente dos avanços tecnológicos, sobretudo da internet, e que embora possa contar - o que nem sempre ocorre - com o mesmo rigor e profissionalismo dos grandes veículos de informação, têm na maioria das vezes um alcance menor do que aqueles, visto que seu escopo se dirige a nichos mais específicos. Todavia, esta diferenciação é ainda bastante tênue quando o assunto é o pouco rigor acerca da análise do legado marxista, pois pode-se encontrar profissionalismo jornalístico, ou a falta dele, tanto em uma como em outra dessas esferas. Portanto, parece-nos mais sensato pensar que o critério a nortear nossa análise sobre o papel da mídia em geral não pode basear-se naquela diferenciação, visto ser possível encontrar distorções e falsificações tanto numa quanto noutra. Assim, se o foco recair a qualidade das análises, os meios de comunicação, sejam tradicionais ou alternativos, que coadunam de 
posições conservadoras, ou até mesmo reacionárias, estão mais propícios a reproduzi-las por questões político-ideológicas.

Veja-se, por exemplo, o número de veículos de comunicação que, a partir de 2013, embora alguns deles até mesmo antes das manifestações que ganharam as ruas neste período, deram uma guinada à direita. Sobre isso, cumpre falar do caso da Rádio Jovem Pan, por ter sido um exemplo emblemático. Em um artigo intitulado "A nova sintonia paulistana”, publicado pela Revista Piauí, a jornalista Julia Dualibi explora esta mudança de direção da Rádio, cuja audiência nacional é considerável. 7 É bem verdade que o artigo tem como foco o sentimento antipetista que passou a pautar a linha editorial da sua grade de programação. Nomes como os de Reinaldo Azevedo, Marco Antônio Villa, Rodrigo Constantino, entre outros, diariamente inundavam os ouvintes com críticas severas aos governos petistas, seja na esfera federal, estadual ou municipal.

A Rede Globo, particularmente um de seus canais, a Globo News, enveredou por caminho análogo. Em 2014, por exemplo, Willian Waack, que apresentava à época o programa Globo News Painel, realizou um episódio, "Direita e Esquerda no Brasil", cuja chamada se comprometia a discutir as vertentes ideológicas na política nacional, mas que na prática, até pelos três convidados daquele dia (Luís Felipe Pondé, Reinaldo Azevedo e Bolivar Lamounier), acabou se convertendo numa série de críticas dirigidas ao campo da esquerda. O programa teve uma segunda edição alguns meses depois com os mesmos convidados, seguindo o mesmíssimo roteiro.

Poderíamos ainda mencionar alguns jornais e revistas de grande circulação, como a Folha de São Paulo, o Estado de São Paulo e a Revista Veja, que por meio de seus editoriais, matérias e capas sensacionalistas, atuaram abertamente contra o primeiro governo de esquerda no Brasil. De modo geral, basta apenas apontar como alguns dos principais veículos da chamada mídia tradicional se posicionaram firme e abertamente contra o governo petista. Mas essa demonização da esquerda também fora acompanhada de críticas mais pontuais, isto é, de ordem supostamente teóricas, voltadas contra Marx e o marxismo. Sobre este ponto, em especial, citaremos alguns outros exemplos, os quais, para nosso escopo, serão demasiadamente úteis.

Além da já mencionada Rede Globo, outras emissoras de televisão também adotaram abertamente uma postura conservadora, aproveitando-se dos avanços do conservadorismo político e moral. Este é o caso de emissoras como Rede TV - cuja grade está disponível na programação televisiva aberta -, mas também da CNN Brasil - emissora que passou a atuar recentemente no país, embora restrita a assinantes - as quais, nos últimos meses, subiram o tom em relação às críticas à esquerda e ao marxismo. $\mathrm{Na}$ Rede TV, por exemplo, há um programa, “Opinião no ar”, conduzido pelo jornalista Luís Ernesto Lacombe, que se tornou um espaço de críticas antissocialistas. Selecionamos um desses programas ${ }^{9}$, no

\footnotetext{
${ }^{7}$ Disponível em: < https://piaui.folha.uol.com.br/materia/a-nova-sinfonia-paulistana $>$. Acesso em 12/06/2021.

${ }^{8}$ Disponível em: < https://www.youtube.com/watch?v=Z421RjUf r8 >. Acesso em 12/06/2021.

9 Disponível em: < https://www.redetv.uol.com.br/jornalismo/OpiniaoNoAr/videos/opiniao-no-ar/o-discurso-daesquerda-prega-um-mundo-idealizado-critica-economista $>$. Acesso em: 28/06/2021. Entretanto, para quem se interessar,
} 
qual o próprio âncora, ao se referir ao socialismo, faz a seguinte afirmação: “Como alguém pode defender ideias não dão certo, não deram certo e não darão certo economicamente. O que a Argentina tem feito, tá tudo errado lá". A seguir, seu interlocutor complementa o comentário de Lacombe: "O discurso de esquerda prega um mundo idealizado. Então nada está bom, porque nada é perfeito. A partir do momento que você olha o mundo real você percebe que não deu certo e que não dará certo. O desastre econômico que vivemos na era Dilma estava ligado ao segundo mandato do Lula. Começa ali a explosão do gasto público e a deterioração fiscal. O que a Dilma fez foi pisar no acelerador”. O caso da CNN Brasil não é diferente. A emissora, que é uma filial da CNN americana, tem em sua grade programas que, embora suscitem algum debate e respeitem a pluralidade de opiniões, procuram claramente fortalecer os valores conservadores. Em um deles, “O grande debate”, a figura do jovem advogado Caio Coppolla, é a notação mais clara disto. Seus comentários, atravessados de preconceitos e repletos de imprecisões teóricas e históricas, revelam um esforço hercúleo para vender a imagem de uma esquerda autoritária, que por vezes tornou-se alvo de críticas não só de seus interlocutores, mas até mesmo da própria mediação do programa. ${ }^{10}$

Em um artigo pretensiosamente intitulado "Eu acuso"11, publicado no jornal Folha de São Paulo, no dia 04/11/2013, o filósofo Luís Felipe Pondé, que se autointitula um pensador conservador, faz uma taxativa afirmação logo no primeiro parágrafo de seu texto. Afirma o autor: "Muitos alunos de universidades e do ensino médio estão sendo acuados em sala de aula por recusarem a pregação marxista. São reprovados em trabalhos ou taxados de egoístas e insensíveis". Em outro artigo, publicado por este mesmo Jornal, em 03/10/2016, Pondé recuperou uma frase dita em sua primeira entrevista ao programa Roda Viva da TV Cultura, em 2011, segundo a qual "O Viagra fez mais pela humanidade do que 200 anos de marxismo".

\footnotetext{
outros programas, todos gravados e disponibilizados na Internet, possuem generalizações parecidas. Falo em generalizações, pois, durante este programa, há uma tentativa tácita, a começar por Lacombe, de reduzir Venezuela, Argentina e Brasil (sobretudo durante o governo petista) de serem países socialistas, numa total sintonia ideológica e em suas práticas políticas e econômicas, o que não é verdadeiro. Nos casos argentino e brasileiro, estas sociedades jamais presenciaram um processo de planificação econômica, bem como um processo de socialização dos meios de produção. Ambos os governos foram eleitos no interior do jogo democrático liberal burguês e jamais transgrediram os limites de uma economia de mercado. Ademais, nos dois casos, os partidos de esquerda que chegaram ao poder, por meio do sistema eleitoral, saíram por meio do voto e não recusaram os resultados nas urnas. Aqui, percebe-se claramente que, para os comentadores do referido programa, pouco importa o resultado das urnas, a decisão soberana de um povo em relação a seus rumos políticos, econômicos e sociais. O que importa, realmente, é que aqueles grupos ou partidos políticos com os quais se identificam não permitam que opositores ou dissidentes cheguem ao poder. No caso específico do Brasil, chama atenção o fato de que a própria esquerda fora crítica das políticas econômicas e sociais do governo petista. que, bem afastada das ideias de Marx, empreendeu um "reformismo fraco", como afirma André Singer em seu livro "Os sentidos do lulismo" (2012) ou Jessé Souza em "A ralé brasileira" (2009) e "A elite do atraso" (2017).

10 Disponível em: <https://noticiasdatv.uol.com.br/noticia/televisao/monalisa-perrone-da-patada-ao-vivo-em-caiocoppolla-por-critica-debate-na-cnn-41756>. Acesso em: 29/06/2021.

11 O título do primeiro artigo citado é uma clara alusão ao famoso artigo-manifesto de Émile Zola, "J'Accuse!", publicado por ocasião do famoso Caso Dreyfus, em 1898, que dividiu a França, em que o escritor faz veementes acusações ao governo e aos militares franceses por conta da prisão do capitão Alfred Dreyfus, de origem judia, e que fora preso e condenado por um suposto ato de traição ao país durante a Guerra Franco-Prussiana. Já o segundo, conforme explicitado, refere-se a uma frase, dita por ocasião de uma entrevista concedida pelo filósofo ao Programa Roda Viva, da TV Cultura, em 2011. Ambos os artigos, todavia, só estão disponíveis para assinantes do Jornal Folha de São Paulo. Por isso, não disponibilizamos os links.
} 
Na esteira de Pondé, Marcelo Madureira, vinculado à Rádio Jovem Pan, critica em um vídeo publicado em 14/03/2018, a edição pela Editora Boitempo de um livro intitulado “O Capital para crianças". No vídeo, ele faz algumas afirmações estapafúrdias. Vejamos: "Qual é a ideia de ficar explicando às crianças um negócio que comprovadamente já mostrou que não dá certo na vida real”. Embora o humorista, alçado pela emissora à condição de analista político, alegue ser "favorável a toda e qualquer difusão de ideias", arremata a seguir, não sem invocar sem qualquer rigor Yuval Harari e Richard Dawkins, que o marxismo se transformou em religião e, por ser contra o ensino religioso, não vê como proveitoso um livro sobre o pensamento marxista voltado para crianças. ${ }^{12}$

Reinaldo Azevedo, em um artigo publicado no site da UOL em 01/04/2019, “A dimensão espiritual das galinhas, Marx, açúcar e ensinamentos de Araújo!”, cujo foco é analisar a política externa brasileira do Governo Bolsonaro, faz uma afirmação no mínimo curiosa: “Karl Marx — que convém ser lido para ser odiado - tem uma tirada interessante no livro $A$ Ideologia Alemã, escrito em parceria com Engels. Vai uma citação de conteúdo — não é literal. Ele observa que os franceses acabaram ficando com a Alsácia-Lorena porque se ocupavam de colonizar a região; já os alemães procuravam demonstrar, no seu processo de ocupação, a superioridade de sua filosofia". ${ }^{13}$ Não seria demasiadamente pedante reforçar o inexplicável trecho: "Karl Marx - que convém ser lido para ser odiado".

O historiador Marco Antônio Villa, no Programa Primeira Hora da Rádio Bandeirantes, em 16/09/2019, faz a seguinte afirmação ao comentar a influência do marxismo na política brasileira, em especial entre os membros do PC do B: "Ser comunista no final da segunda década do século XXI é inacreditável". ${ }^{14}$

Já Rodrigo Constantino, num vídeo publicado no site da Rádio Jovem Pan, em 21/12/2019, no qual o comenta um texto do Ministro das Relações Exteriores à época, Ernesto Araújo, fala sobre o Foro de São Paulo e a suposta ameaça, representada pelo comunismo, que pode se alastrar por toda a América Latina. E complementa seu raciocínio comentando uma ideia lançada por Araújo: "Vão já, portanto, quase 30 anos em que o marxismo está cavando túneis por baixo da superfície, aparentemente segura e tranquila da sociedade liberal. Eu não discordo". ${ }^{15}$

Até mesmo jornais de menor expressão nacional, como é o caso Hora Extra de Goiânia, tem enveredado por este caminho. Em um artigo publicado em 06/06/2020, intitulado "Karl Marx - o terraplanista da economia", o articulista Jeovane Barboza faz as seguintes afirmações: "Seus pensamentos per si já nasceram refutados, assim como muitos outros pensamentos socialistas. A maisvalia entra totalmente nesse contexto, ao afirmar, de forma equivocada que o valor de algo é definido

\footnotetext{
12 Disponível em: <https://jovempan.com.br/arquivo/marcelo-madureira/o-que-karl-marx-acharia-de-versao-adaptadapara-criancas-de-o-capital.html>. Acesso em 18/06/2021.

13 Disponível em:https://reinaldoazevedo.blogosfera.uol.com.br/2019/04/01/a-dimensao-espiritual-das-galinhas-marxacucar-e-ensinamentos-de-araujo/?cmpid=copiaecola. Acesso em 18/06/2021.

${ }^{14}$ Disponível em: https://www.youtube.com/watch?v=di XdyRNxV. Acesso em 18/06/2021.

${ }_{15}$ Disponível em: <https://jovempan.com.br/opiniao-jovem-pan/comentaristas/rodrigo-constantino/constantino-ameacacomunista-nunca-esteve-tao-forte.html. $>$. Acesso em 19/06/2021.
} 
objetivamente pelo seu tempo de produção - o famoso valor trabalho. Porém a realidade é diferente. Os humanos agem de forma diferente. Nós agimos de acordo com a "teoria subjetiva do valor", onde o mesmo é definido pela vontade individual de cada um, das vontades de cada pessoa" [sic]. Pouco mais a frente, desfecha com a seguinte análise: “Qualquer ser humano consegue enxergar a economia por uma premissa básica como 'Oferta e Demanda' de forma bem natural e assim refutar pensamentos de Karl Marx que grande parte da sociedade acredita. Pessoas que defendem o Comunismo, normalmente demonizam trocas-voluntárias, tentando criar uma retórica falha de que o capitalismo é algo ruim. Acreditam que em um estado que obriga as pessoas a dividirem os frutos de seus trabalhos

14 igualitariamente, independente se todos trabalham também igualitariamente, desprezando totalmente o direito à propriedade e às liberdades individuais. Renegam o capitalismo e o livre mercado e atribuem ao estado o poder de centralizar e planificar (regular e planejar) a economia. Por isso Karl Marx era um 'terra-planista' econômico" [sic]. ${ }^{16}$

Eis alguns exemplos relativamente recentes de como a mídia tradicional trata o assunto ou, pelo menos, passou a tratá-lo após a chegada de um partido de esquerda ao poder. Mas essas posições são ainda bastante educadas quando comparadas às posições adotadas pela mídia alternativa, que, como já dissemos, está voltada a grupos específicos, embora não contando com o alcance da mídia tradicional.

É este o caso do site do Instituto Mises Brasil, que se direciona a um público bem recortado, formado majoritariamente por liberais ou simpatizantes do liberalismo e que leva o nome do economista liberal austríaco Ludwig von Mises. É interessante notar que, diante da crise política e dos escândalos de corrupção que acometeram o Brasil durante o período em que o PT esteve no poder, muitos eleitores foram atraídos por grupos análogos ao do mencionado Instituto. Mas vejamos um artigo, publicado no dia 28/04/2013, com o título "Marxismo: a máquina assassina” no site do Instituto. Diz a certa altura o seu autor, R.J. Rummel: “De todas as religiões, seculares ou não, o marxismo é de longe a mais sangrenta — muito mais sangrenta do que a Inquisição Católica, do que as várias cruzadas e do que a Guerra dos Trinta Anos entre católicos e protestantes. Na prática, o marxismo foi sinônimo de terrorismo sanguinário, de expurgos seguidos de morte, de campos de prisioneiros e de trabalhos forçados, de deportações, de inanição dantesca, de execuções extrajudiciais, de julgamentos teatrais, e de genocídio e assassinatos em massa". ${ }^{17}$

Mas, sem dúvida, o maior crítico do marxismo nas redes sociais, em geral, e de Marx, em particular, é Olavo de Carvalho. O ex-comunista, ex-astrólogo e ex-colunista do Diário do Comércio de São Paulo, e de alguns outros veículos de comunicação tradicionais, que não conta com uma formação regular, mas que se autointitula filósofo, consegue arregimentar uma legião de seguidores por meio de seus cursos livres, canais e páginas nas redes sociais, sendo grande parte de seu público formado por

\footnotetext{
$16 \quad$ Disponível em: $\quad<$ https://jornalhoraextra.com.br/coluna/karl-marx-O-terra-planista-daeconomia/?fbclid=IwAR12jefEQ3snl5UA5B1a53QUde3SZSa238wrdK0nSnIblTnrrkMALrVvh9w >. Acesso em: 10/07/2021.

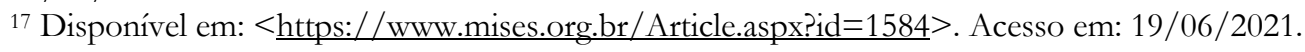


jovens. Poderíamos até mencionar, como exemplo, um ou outro vídeo de Olavo de Carvalho, bem como um ou outro texto, seja extraído de livros ou artigos por ele escritos. Todavia, é muito fácil encontrá-los, à medida que são públicos e circulam na internet com rapidez por meio de seus e de outros canais. Olavo, que já pertenceu ao PCB, rompendo posteriormente com o partido, tornou-se, pelo menos desde os anos 1980, um militante na luta contra a esquerda. A narrativa olavista, que poderia ser enquadrada como conspiratória, é a de que a esquerda mundial (que ele simplesmente não define) tem como estratégia a tomada do poder a partir de uma guerra travada no campo cultural, o que comumente é chamado “marxismo cultural”. Na visão do autor, vendo-se impossibilitada de promover uma revolução proletária, tal como propugnada por Marx, a esquerda passou a adotar como estratégia as ideias do pensador marxista italiano Antônio Gramsci e dos filósofos vinculados à Escola de Frankfurt, em especial Theodor Adorno, Max Horkheimer e Walter Benjamin. ${ }^{18}$ Em relação ao Brasil, Olavo é taxativo quanto ao marxismo: o período entre 1964 e 1985, quando se instalou no país uma ditadura civil-militar, foi marcado pela conivência dos militares, que, embora combatendo os militantes de esquerda, sobretudo a luta armada, permitiram que parte da esquerda ocupasse o espaço cultural das universidades, dos meios de comunicação de massa e da produção cultural (cinema, teatro, literatura etc.), dando prosseguimento a sua guerra contra a sociedade liberal-burguesa, agora, todavia, numa outra frente de batalha, consubstanciada na América Latina pelo Foro de São Paulo. ${ }^{19}$ Essa interpretação, como revela um dos maiores estudiosos deste assunto, João Cezar de Castro Rocha (2021), difundiu-se velozmente, inclusive entre parte das Forças Armadas, em especial o Exército Brasileiro, como revela uma publicação intitulada Orvil. ${ }^{20} \mathrm{O}$ alcance das interpretações de Olavo não pode nem deve ser desconsiderado. Conforme se disse, entre aqueles que seguem suas publicações e seus cursos, há um público jovem considerável. Isso porque as redes sociais (WhatsApp, Facebook, YouTube, Twitter, Instragram, Telegram etc.) passaram a ocupar um papel central na difusão de informações, afetando, sobretudo, a parcela mais jovem da população brasileira, mais ambientada a utilização dessas novas tecnologias. À medida que esta recémcriada midiosfera tornou-se o principal espaço de atuação da chamada mídia alternativa, a proliferação

\footnotetext{
${ }^{18} \mathrm{Na}$ interpretação olaviana, Gramsci é o arquiteto da tese segundo a qual os intelectuais comunistas deveriam deslocar a luta política para o campo cultural. Em relação aos frankfurtianos, os estudos desenvolvidos sobre a indústria cultural teriam sido fundamentais para o avanço esquerda mundial neste campo.

${ }^{19}$ Como afirmam Camila Rocha e Esther Solano (2021, p. 22-23): "Desde a metade de 1990, Carvalho defendia, por meio de livros e artigos de jornais e revistas, a ideia de que o país foi tomado por uma hegemonia exercida por intelectuais de esquerda, que ocuparam posições de prestígio em editoras de livro, nas redações dos principais veículos de comunicação e nos cursos de humanidades das principais universidades do país, mais notadamente na Universidade de São Paulo (USP). De acordo com Carvalho, esses intelectuais seriam incapazes de realizar reflexões profundas sobre o Brasil que se destacassem no panorama intelectual mundial e, portanto, contentavam-se em repetir, de modo irrefletido, chavões inspirados nas últimas modas intelectuais dos Estados Unidos. Para ele, um exemplo dessa reprodução de modismos era a defesa de lutas contra opressões de gênero e raça, conhecidas popularmente como 'pautas identitárias'. Extremamente ativo na internet, ainda em 1998 Carvalho passou a divulgar suas ideias em um blog e, mais tarde, em 2002, em um site colaborativo. No ano de 2004, ele já era tema de pelo menos quatro comunidades de discussão na falecida rede social Orkut, além de ministrar aulas em cursos on-line e realizar transmissões de áudio pelo site Blog Talk Radio, análogos ao que hoje se conhece como podcast'.

${ }^{20}$ O Orvil, que nada mais é do que a palavra "livro" lida de trás para a frente, trata-se de um documento-livro em oposição ao livro "Brasil nunca mais", organizado pela ala progressista da Igreja Católica e da sociedade civil, cujo objetivo é reinterpretar o período da ditadura a partir da visão dos militares, estabelecendo, portanto, o marco de uma guerra de narrativas (Cf. ROCHA, 2021, p. 31-106.)
} 
de páginas, sites, canais conservadores e liberais-conservadores se potencializou muito nos últimos anos (NICOLAU, 2020).

Com efeito, como se tentou demonstrar a partir de alguns exemplos, nos últimos anos Marx e o marxismo foram bombardeados por setores conservadores tanto da dita mídia tradicional quanto da mídia alternativa. De modo que estes ataques, muitas vezes repletos de equívocos interpretativos, seja por desconhecimento ou mesmo má-fé, parecem ter sortido efeito sobre uma parte da população. Do contrário, a invocação do comunismo, como um inimigo a ser combatido, não teria, como se deu em alguns períodos história republicana do século XX, novamente vindo à tona neste início de século e emoldurado as últimas disputas eleitorais, especialmente após as manifestações de Junho de 2013. Um processo como este não poderia deixar de impactar a recepção das teorias marxistas em sala de aula, tornando-se um problema para os professores da área das ciências humanas. Afinal, mais do que em qualquer outro momento da história contemporânea, os alunos têm o acesso ao mundo compreendido na palma de suas mãos.

\section{O MARXISMO CULTURAL E O MOVIMENTO “ESCOLA SEM PARTIDO”}

A ideia de que a esquerda aposta suas fichas em uma nova estratégia de tomada do poder fora bastante difundida nos últimos anos, não só no Brasil, mas mundo afora, com a contribuição decisiva de parte dos grandes veículos de comunicação tradicionais e alternativos. Esta suposta estratégia, denominada "marxismo cultural", corresponde ao novo campo de luta escolhido pelos marxistas, a saber: o campo cultural. Os defensores e propagadores desta intepretação partem do pressuposto de que a esquerda monopolizou diversas das instituições culturais que compõe a sociedade civil, inclusive as midiáticas e educativas. De modo que, a partir disso, facilmente concluem que os valores marxistas estão há décadas sendo propalados e, por suposto, emoldurando a formação dos cidadãos, que passam a entender a realidade a partir do conjunto de categorias atinentes a seu universo valorativo, epistemológico e político. Portanto Marx, mas também em larga medida Gramsci, Adorno, Horkheimer e Benjamin, constituiriam as bases teóricas da nova tática de luta política deflagrada pela esquerda. No caso brasileiro, alguns pontos relativos a essa discussão chamam atenção. Em primeiro lugar, a única experiência de um partido de esquerda no poder foi a petista (2002-2016). Ainda assim, tratou-se de uma esquerda absolutamente democrática, responsável por manter grande parte da agenda política e econômica liberal dos governos anteriores, com a única diferença de focar alguns dos grandes problemas sociais tais como a desigualdade e a concentração de renda. Em segundo lugar, os partidos brasileiros mais à esquerda do espectro político no período pós-redemocratização nunca tiveram força eleitoral significativa. Em terceiro lugar, a esquerda brasileira ficou marcada como corrupta - sobretudo após os escândalos do Mensalão, do Petrolão e do desfecho da Operação Lava Jato, que levou Luís Inácio Lula da Silva à prisão, mas cujo efeito não se restringiu ao Partido dos Trabalhadores, afetando todo o campo político da 
esquerda brasileira -, conquanto a corrupção no país venha de longa data e envolva partidos de diversos matizes ideológicos. ${ }^{21}$

O fato é que o discurso acerca do "marxismo cultural" repercutiu fortemente entre grupos políticos conservadores e de extrema direita, sobretudo quanto ao papel do sistema de ensino na suposta difusão dos valores socialistas e comunistas entre crianças, adolescentes e parcela jovem de adultos em idade universitária. Neste sentido, não é mera coincidência que, pari passu ao avanço deste discurso, emergisse no Brasil o movimento denominado "Escola Sem Partido", cuja repercussão na sociedade arregimentou um número significativo de simpatizantes, sobretudo entre os setores mais conservadores. O programa do Escola Sem Partido surgiu a partir de movimentos isolados, quando alguns projetos de lei começaram a transitar em diversas câmaras municipais pelo Brasil. Todavia, ganhou notoriedade a partir de 2015, quando as principais pautas do movimento passaram a ser discutidas tanto nas redes sociais quanto nos grandes veículos de comunicação. Em geral, os signatários deste movimento alegam que o sistema de ensino constitui um espaço de doutrinação ideológica no qual parcela dos professores, aproveitando-se da imaturidade de crianças e adolescentes, no caso da educação básica, e de jovens adultos, no caso das universidades, utiliza a autoridade da qual está investida para difundir valores e ideias marxistas no ambiente escolar e acadêmico.22 O movimento, que afirma representar os interesses de alunos, pais e professores que não coadunam do proselitismo político-partidário-ideológico em sala de aula, manteve por um tempo uma página na internet com o intuito de coletar relatos de estudantes constrangidos por seus professores. A maior parte dos depoimentos apontam para a militância ideológica destes profissionais da educação. Deste modo, uma das pautas do movimento é especificar os limites de atuação dos professores em sala de aula, bem como criminalizar as práticas docentes que destoarem destes limites. $\mathrm{Na}$ ótica dos defensores deste movimento, não é papel da escola discutir temas relacionados à gênero, religião, moral etc., pois estes seriam prerrogativas das famílias e não do professor. Ademais, entre eles há a impressão, não comprovada por nenhum estudo sério, de que grande parte dos professores são militantes de esquerda, que visam corromper as bases da família tradicional. Por conta da natureza desta pauta, parte da comunidade neopentecostal embarcou no movimento. Alguns líderes religiosos passaram a destilar todo tipo de crítica ao "marxismo cultural". Uma dessas lideranças, o Pastor Silas Malafaia, é um dos mais entusiastas do movimento Escola Sem Partido. ${ }^{23}$ Para o referido Pastor, o marxismo é inimigo do cristianismo. Como deixa claro em um de seus canais no YouTube, num programa chamado Verdade Gospel: "Reparem a ideologia comunista. China, Coreia, Cuba, ok! A pouco tempo

\footnotetext{
${ }^{21}$ Evidentemente, parecem contraditórias as afirmações de que a esquerda detém o monopólio dos valores e ideias no campo cultural, embora não consiga traduzir esta força ideológica em vitórias políticas, ou de que ela é a única responsável pelos processos de corrupção, os quais historicamente sempre acometeram o país. Se a realidade concreta nega os fundamentos dessas narrativas, o fato é que, do ponto de vista pragmático, isto é, eleitoral e imagético, elas surtiram efeitos deletérios ao campo da esquerda, que não só fora banida do poder, como também amargou derrotas dolorosas nas eleições municipais e estaduais.

${ }^{22}$ Disponível em: < https://g1.globo.com/educacao/noticia/entenda-a-polemica-em-torno-do-escola-sem-partido.ghtml > Acesso em: 04/07/2021.

${ }^{23}$ Disponível em: < https://twitter.com/pastormalafaia/status/764218635455954944> Acesso em: 04/07/2021.
} 
atrás, a União Soviética. Meu amigo, esses caras não toleram religião. Lá na China, eles abriram a economia, mas não abriram pra liberdade de expressão nem liberdade religiosa. Vai lá em Cuba, vai lá! Vai lá em Cuba pra ver se tem moleza pra cristão. Comunista. A ideologia baseada em Marx prega o ateísmo. Religião, religião é ópio [claramente aludindo à frase de Marx segundo a qual a religião é o ópio do povo']. Religião é uma coisa que tem que ser extirpada. Foram o que eles doutrinaram e pregaram o tempo inteiro" [sic]. ${ }^{24}$ Não deixa de chamar a atenção as afinidades eletivas entre as pautas do movimento Escola Sem Partido e as pautas moralistas de algumas lideranças religiosas, ambas ancoradas no medo da suposta destruição dos valores tradicionais face à doutrinação marxista.

Decerto, o movimento Escola Sem Partido ganhou muitos adeptos entre grupos conservadores, ultraconservadores e setores da comunidade evangélica. Os pressupostos que dão sustentação a maioria das bandeiras erguidas por este movimento são facilmente identificáveis. Há pelo menos dois pressupostos bastante nítidos: um de ordem moral; outro de ordem psicológica. Em relação ao primeiro deles, seus representantes partem da ideia de que os professores, sobremaneira os das Ciências Humanas, são moralmente torpes e, de modo calculado e ardiloso, tornam a escola um palanque político com vistas a ideologizar as aulas. Embora não estejam respaldados por nenhuma pesquisa que legitime tal conclusão, os defensores do Escola Sem Partido, por meio de generalizações e simplismos de toda a sorte, não mediram esforços no sentido de difundi-la perante a opinião pública. Quanto ao segundo pressuposto, partem da ideia de que os alunos são como "tábulas rasas" (para me fazer valer da expressão do filósofo liberal inglês John Locke), e que, portanto, estariam psicologicamente suscetíveis às sugestões (entendase "lavagem-cerebral") arbitrariamente impostas por seus professores. Em decorrência disso, seus membros deflagraram uma verdadeira "caça às bruxas", estimulando alunos em todos os níveis de ensino a gravarem e divulgarem os abusos cometidos pelos professores. Alguns profissionais da educação foram intimados a depor ou mesmo processados por familiares de alunos ou por membros do movimento. ${ }^{25}$

É difícil precisar se este movimento é um efeito direto do papel exercido pelas mídias tradicionais e alternativas, mas não há dúvida de que, com a profusão das críticas dirigidas à esquerda, especialmente ao marxismo, ele se fortaleceu muito. Pode-se avistar algumas aproximações entre as críticas ao marxismo, destacadas na primeira seção, e o conteúdo das pautas defendidas pelo Escola Sem Partido.

Comecemos pela ideia, presente em parte dos vídeos e artigos acima selecionados, sobre o monopólio exercido pela esquerda sobre o campo cultural. Já vimos que, segundo alguns nomes importantes das mídias tradicional e alternativa, a esquerda teria se apropriado dos meios de difusão de valores e ideias (o "marxismo cultural"), entre eles do sistema de ensino. Ora, quase toda retórica do Escola Sem Partido se desenvolve em cima deste pressuposto, e não por acaso os professores aparecem como agentes doutrinadores cujo único objetivo é o de reforçá-lo. Outro ponto de convergência remete

\footnotetext{
${ }^{24}$ Disponível em: < https://www.youtube.com/watch?v $={ }_{\mathrm{OCD}}$ (whfiiUac. $>$ Acesso em: 04/07/2021.

25 Disponível em: < https://www.brasildefato.com.br/2018/10/29/deputada-eleita-pelo-psl-estimula-estudantes-adenunciarem-professores/>. Acesso em: 04/07/2021.
} 
à interpretação de que os marxistas têm uma grande influência sobre os rumos da política nacional. Há, neste caso, a impressão de que os professores são em sua maioria marxistas e que, conscientes da influência sobre seus alunos, aproveitam qualquer espaço para exercê-la em vista da formação de novos comunistas e socialistas. Cumpre destacar ainda o fato de que um processo tão sorrateiro como este tem por intuito drenar e destruir os valores tradicionais e as liberdades individuais. Qualquer um dos trechos tratados na primeira seção poderia ser facilmente subscrito por um integrante do Escola Sem Partido. Por último, em ambos os casos nada do que é afirmado está ancorado em provas. Trata-se apenas de especulações. Por isso, acreditamos que só uma análise criteriosa, logicamente organizada e assentada em dados concretos, histórica e socialmente validados, possa descontruir esse tipo de crítica.

\section{COMO O MARXISMO PODE AJUDAR A RESPONDER ESSAS CRÍTICAS?}

Nesta seção, analisaremos algumas das narrativas apresentadas no início do texto. Com isso, vislumbra-se verificar os fundamentos dessas críticas à luz de algum parâmetro lógico-racional, que comporte alguma coerência discursiva. Trata-se, pois, como diz João Cézar de Castro Rocha (2021), de passar da caricatura à caracterização e revelar a retórica do ódio e a sua "lógica de Napoleão de hospício". ${ }^{26}$ Claro que o título desta seção sugere que nos basearemos no referencial marxista para realizar nosso intento. Todavia, não é demais alertar, Marx não lidou exatamente com essas críticas em sua época, embora seja possível revitalizar alguns conceitos e categorias de sua obra com vistas a desconstruí-las.

Comecemos pelos dois artigos de Pondé. No primeiro deles, o filósofo conservador afirma que alunos estão sendo punidos por não se submeterem ao marxismo apregoado por seus professores, o que, aliás, lembra muito o discurso defendido pelo Escola Sem Partido. A pergunta que se levanta é a seguinte: quais estudos balizam sua afirmação? Trata-se de mera opinião? Em que dados coletados por meio de uma pesquisa ou pesquisas sérias e rigorosas Pondé se baseou para inferir conclusão tão taxativa? Alguns poderão objetar que se trata de um artigo de opinião. Sim, disso sabemos. Mas a questão principal é: embora todos tenham a liberdade de expor suas opiniões, o que torna uma opinião referência de verdade sobretudo quando assentada única e exclusivamente em impressões pessoais, sem o respaldo de dados rigorosamente extraídos e analisados da realidade concreta? Ora, não é papel do filósofo pensar esta realidade com rigor e radicalidade, no sentido marxista de ir à raiz do problema? Pondé simplesmente ignora esta realidade e deduz, a partir de uma mera opinião, uma conclusão absolutamente ideológica. Marx e Engels (2007, p. 35-36) esclarecem, em um trecho da Ideologia Alemã, como as ideias podem se autonomizar da práxis social:

\footnotetext{
${ }^{26}$ O que o autor denomina "lógica de Napoleão de hospício" refere-se ao esforço por parte de grupos fundamentalistas para fazer valer seus valores, geralmente baseados em impressões desprovidas de qualquer laivo de racionalidade ou de comprovações contundentes.
} 
Desde o início, portanto, a consciência já é um produto social e continuará sendo enquanto existirem homens. A consciência é, naturalmente, antes de tudo a mera consciência do meio sensível mais imediato e consciência do vínculo limitado com outras pessoas e coisas exteriores ao indivíduo que se torna consciente; [...] a partir do momento em que surge uma divisão do trabalho material e espiritual. A partir desse momento, a consciência pode realmente imaginar ser outra coisa diferente da práxis existente, representar algo realmente sem representar algo real - a partir de então, a consciência está em condições de emancipar-se do mundo e lançar-se à construção teoria, da teoria, da teologia, da filosofia, da moral etc. "puras".

O segundo artigo é ainda mais problemático. Pondé afirma que o Viagra trouxe mais benefícios à humanidade do que 200 anos de marxismo. Qual o propósito do autor em comparar um medicamento para ereção masculina com um sistema de pensamento? Trata-se de coisas de mesma natureza, gênero e grandeza? Há nessa crítica um profundo desrespeito e desconhecimento histórico sobre a importância das lutas proletárias, iniciadas no século XIX e continuadas no decorrer do século XX e XXI, para a conquista de direitos civis, políticos e sociais da classe trabalhadora. Dizer que um pênis ereto é, em termos valorativos, superior a essas conquistas, corresponde a misturar "alhos e bugalhos", a partir de um fundamento claramente sexual e machista, como se a atividade sexual masculina pudesse servir de critério para mensurar e desmerecer a luta de uma classe social por melhores condições de vida. A questão que se impõe é: o que uma coisa tem a ver com a outra? Mais do que isso, como não reconhecer a luta dos trabalhadores como um ponto de inflexão nas conquistas e avanços de seus direitos no transcorrer dos séculos XIX e XX? Marx e Engels (2012, p. 39), no famoso Manifesto do Partido Comunista, não só identificaram, mas também prenunciaram que só por meio da luta política seria possível aos trabalhadores modificar suas condições e superar a exploração:

\footnotetext{
A história de todas as sociedades até hoje existentes é a história das lutas de classes. Homem livres e escravo, patrício e plebeu, senhor feudal e servo, mestre de corporação e companheiro, em resumo, opressores e oprimidos, em constante oposição, têm vivido numa guerra ininterrupta, ora fraca, ora disfarçada; uma guerra que se transformou sempre ou por uma transformação revolucionária da sociedade inteira, ou pela destruição das duas classes em conflito.
}

Vejamos agora a crítica de Marco Antônio Villa, para quem ser marxista no século XXI é um despropósito. É bem verdade que a sociedade capitalista que Marx analisou não é a nossa. Muita coisa se complexificou do século XIX para cá. Todavia, cumpre indagar: será que o cabedal teórico, metodológico e categorial marxista teria, todo ele, se tornado obsoleto? Esta parece ser a conclusão de Villa. Mas se analisarmos mais profundamente a sociedade contemporânea, sobretudo nas últimas décadas, em decorrência das transformações ocorridas no campo informacional, não se poderá negar que conceitos como os de luta de classes e ideologia, por exemplo, não se esgotaram enquanto força explicativa de nosso tempo presente. Há luta de classes atualmente? Bem, basta observarmos os ataques aos direitos trabalhistas, ao sistema previdenciário e aos demais direitos sociais no Brasil nos últimos anos. A quem esses ataques beneficiam? Aos trabalhadores ou àqueles que dispõem dos meios de produção e concentram o capital? Quem detém o monopólio da informação no Brasil? Quem são os donos dos 
grandes meios de comunicação no Brasil? Os trabalhadores ou a grande burguesia? O equívoco de Villa repousa na defesa do mito liberal segundo o qual a política é regida por ambições pessoais de atores proeminentes que, suspostamente, se relacionam livremente. Ele não consegue visualizar o caráter classista dessas relações, nem sequer o modo como estas são determinadas pelas condições materiais inerentes ao sistema produtivo da sociedade burguesa. Parece-nos inegável que alguns conceitos marxistas ainda dispõem de vitalidade e nos ajudam a explicar a realidade social da qual fazemos parte, de modo que ser marxista no século XXI, ao contrário do que afirma Villa, está longe de ser um despropósito, visto que, embora Marx tenha denunciado e analisado as mazelas do modo de produção capitalista há quase 200 anos, uma parte delas se mantiveram e até mesmo se agudizaram no decorrer dos séculos XX e XXI. Não reconhecer que a ideologia predominante, sobretudo no ocidente, é a liberalburguesa, e que a luta de classes ainda se faz presente em nossa sociedade, conquanto numa versão bem mais complexa do que na época de Marx, é que me parece desproposital (ou melhor, proposital, embora ocultada por meio da naturalização do discurso liberal).

E quanto ao comentário de Rodrigo Constantino, segundo o qual o marxismo estaria cavando túneis por baixo da aparentemente tranquila e segura sociedade liberal? Pelo menos desde o século XIX, o Brasil se inclinou para uma economia política baseada nos cânones do pensamento liberal. Com isso não se está afirmando que o liberalismo que se desenvolveu aqui é o mesmo que se desenvolveu nos países Europeus e nos Estados Unidos. Tratou-se de um liberalismo oligárquico e excludente, resultante de um sistema colonial, sobre o qual se constituiu a modernização brasileira, mas que não fora completamente superado durante este processo. Muito pelo contrário. Como disse o sociólogo Francisco de Oliveira (2003), o capitalismo brasileiro se constituiu sob as ruínas de um sistema escravocrata, patrimonialista, patriarcal, altamente hierarquizado, que vigorou por séculos, dando origem a um verdadeiro “ornitorrinco", isto é, a um país no qual modernidade e atraso convivem lado a lado. De fato, nunca vivemos um liberalismo, seja político ou econômico, à exemplo das grandes potências mundiais. Nosso liberalismo fora tutelado por uma herança escravocrata, portanto uma mentalidade senhorial patriarcal, escravocrata, patrimonialista e mandonista - que deu origem a uma experiência social anômala (SCHWARCZ, 2014). Neste sentido, há uma idealização por parte de Constantino acerca de nosso liberalismo, caracterizado pela tentativa de transplantar (para me fazer de um conceito caro a Darcy Ribeiro) um modelo social e cultural exportado para um país, no caso o Brasil, incapaz de livrar-se de seu passado autoritário (SCHWARCZ, 2019). Não seria o marxismo uma reação à incompetência de nossos liberais e ao próprio liberalismo à brasileira? Constantino simplesmente ignora essas questões.

E o que dizer do artigo de Jeovane Barboza, publicado no Jornal Hora Extra? Há erros interpretativos graves sobre a teoria do valor do trabalho e o mais-valor em Marx. O filósofo alemão, que parte da teoria do valor do trabalho tal como proposta por Adam Smith e David Ricardo, contudo subvertendo-a, não concebe o valor de uma mercadoria apenas a partir do quantum de trabalho nela contida. Há, e aqui reside o verdadeiro sentido do conceito de mais-valor marxista, uma apropriação 
indébita, por parte da burguesia, da força de trabalho socialmente necessária à produção da mercadoria, que recaí sobre o proletário. Ademais, o que seria a "teoria subjetiva do valor"? O articulista a define como "vontade individual de cada um, das vontades de cada pessoa". Se a "naturalidade das trocas" significa que cada indivíduo pode auferir a uma mercadoria o valor que desejar, há, sem dúvida, uma incompreensão sobre o papel exercido pelas forças sociais e historicamente dadas na estipulação dos valores médios das mercadorias, assim como uma total negligência em relação ao monopólio dos meios de produção e à exploração da força de trabalho (ela própria uma mercadoria) no interior do modo de produção capitalista. Aliás, sobre este ponto, Marx não deixa qualquer dúvida, como podemos ver numa passagem do Livro I de O Capital:

[...] essa cisão do produto do trabalho em coisa útil e coisa de valor só se realiza quando a troca já conquistou um alcance e uma importância suficientes para que se produzam coisas úteis destinadas à troca e, portanto, o caráter de valor das coisas passou a ser considerado no próprio ato de sua produção (MARX, 2011, p. 148).

Mais à frente, Marx enfatiza o processo pelo qual o capital se apropria e explora quem verdadeiramente produz valor, a força de trabalho. A esse respeito, afirma o filósofo alemão: “O capital é trabalho morto, que, como um vampiro, vive apenas da sucção de trabalho vivo, e vive tanto quanto mais trabalho vivo ele suga" (MARX, 2011, p. 307).

Contudo, a interpretação que passou a circular com força entre os críticos da esquerda, e por suposto de Marx, que atuam na mídia tanto tradicional quanto alternativa, foi a de Olavo de Carvalho. Até mesmo críticos como Rodrigo Constantino ${ }^{27}$ e Luís Felipe Pondé28 - embora este último nunca tenha admitido - reproduzem em seus artigos e vídeos o fulcro da interpretação olaviana. Esta, conforme assinalamos, resume-me à afirmação segundo a qual a esquerda brasileira, mas também a esquerda mundial, modificou a sua estratégia de luta apostando na conquista da hegemonia do campo cultural. Destarte, o marxismo teria se espraiado pelos meios intelectuais e de comunicação no intuito de preparar ideologicamente a aceitação de um processo pacífico, conquanto revolucionário em seu objetivo último, que se daria por dentro do sistema democrático-liberal. Assim, na visão de Olavo de Carvalho, além dos

\footnotetext{
${ }^{27}$ No caso de Constantino ver o vídeo a seguir: Disponível em: $<$ https://www.youtube.com/watch?v=n AM46MXpeE $>$. Acesso em: 27/06/2021.

${ }^{28}$ No caso de Pondé, ver o vídeo a seguir: Disponível em: <https://www.youtube.com/watch?v=iqZ43J2cij4>. Acesso em: 27/06/2021. Mas apesar de o autor ser um crítico do que denomina "marxismo cultural”, ele não se revela favorável ao movimento "Escola Sem Partido", pelo menos do ponto de vista jurídico, como deixa claro no vídeo a seguir: Disponível em: $<$ https://www.youtube.com/watch?v=ff1KcxlxAac $>$. Acesso em: 27/06/2021. Ainda assim, sem qualquer comprovação empírica, Pondé afirma, neste último vídeo, que a despeito de ser contrário à formulação de uma lei que criminalize o proselitismo de professores em sala de aula, muitos de seus colegas são marxistas, e que, por isso, muitos alunos reclamam do suposto autoritarismo teórico a qual estão submetidos. Tais fatos seriam provas suficientes de que a influência do marxismo no ambiente acadêmico e escolar é inquestionável. O raciocínio de Pondé é a própria negação dos métodos dedutivo e indutivo. Em outros termos, o autor ou deduz que há o marxismo cultural, como uma verdade inegável, ou se apega a casos isolados para, a partir daí, induzir seus interlocutores à conclusão de que todos os professores são marxistas e que todos os alunos sofrem diante disso. Todavia, não há, por parte de Pondé, qualquer prova ou dado contundente que legitime tal afirmação. Fica-se assim no campo das impressões e das opiniões ao qual, desde a Antiguidade, os principais filósofos se opuseram veementemente. Então, o que seria isso senão "má-fé”?
} 
grandes veículos de comunicação, um dos espaços de atuação dos “intelectuais orgânicos” do socialismo - para me fazer valer de um conceito caro a Antônio Gramsci - é o sistema de ensino. Neste sentido, os professores, seja os do ensino básico ou os do ensino superior, seriam agentes difusores da ideologia e dos valores socialistas em sala de aula, aproveitando-se da ingenuidade e imaturidade de seus alunos com vistas a doutriná-los. Aliás, a narrativa do "marxismo cultural”, também presente, como vimos, entre os simpatizantes do movimento Escola Sem Partido, não teve início com Olavo de Carvalho. Ao contrário do que se possa pensar, sua origem é bem mais remota. Ela se origina, como demonstra Iná Camargo Costa (2020), na esteira dos movimentos nazifascistas europeus das primeiras décadas do século XX.

23 Sobretudo a propaganda nazista lançou mão de um expediente bastante difuso em nosso tempo presente: a falsificação informacional (o que hoje chamaríamos "Fake News") com vistas a legitimar uma teoria conspiratória segundo a qual os judeus, em grande parte marxistas, vislumbravam corromper os valores da civilização cristã-ocidental. Os meios intelectuais, que incluía o sistema educacional, além dos meios artísticos e midiáticos, seriam uma das formas de atuação dos judeus na consecução desta confabulação global. Conforme a autora esclarece, ainda na primeira metade daquele século, nos Estados Unidos, movimentos de extrema-direita, que reuniam religiosos, políticos (tanto democratas quanto republicanos), empresários e grupos sectários supremacistas brancos e misóginos, exumaram algumas das estratégias nazifascistas e, sobretudo após a Segunda Guerra Mundial, deflagraram uma verdadeira "caça às bruxas" aos supostos comunistas infiltrados tanto no funcionalismo público quanto nos meios midiáticos, intelectuais e artísticos, cujo ápice, indubitavelmente, fora o "macarthismo". ${ }^{29}$

Mais recentemente, no início deste século, o conceito veio novamente à tona com grupos ultraconservadores estadunidenses. Steve Bannon, que esteve à frente da campanha eleitoral de Donald Trump, é um de seus principais arquitetos nos Estados Unidos, enquanto no Brasil, o nome mais emblemático é o de Olavo de Carvalho. Como é sabido, tanto Bannon quanto Carvalho tiveram uma participação bastante ativa na campanha eleitoral de Jair Messias Bolsonaro. ${ }^{30} \mathrm{O}$ inimigo a ser combatido foi delineado durante a campanha: o marxismo cultural. Como revela uma passagem do programa de governo do PSL, partido pelo qual Bolsonaro fora eleito em 2018: "Nos últimos 30 anos o marxismo cultural e suas derivações como o gramscismo se uniu [sic] às oligarquias corruptas para minar os valores da Nação e da família brasileira”. Pouco mais a frente, não há qualquer dúvida quanto ao campo no qual a batalha contra a esquerda se travará: “Além de mudar o método da gestão, na Educação também precisamos revisar e modernizar o conteúdo. Isso inclui a alfabetização, expurgando a ideologia de Paulo Freire". ${ }^{31}$ Fica clara a influência exercida tanto pelo movimento Escola Sem Partido quanto pelos críticos

\footnotetext{
${ }^{29}$ Referência ao senador estadunidense Joseph McCarthy, que, nos idos de 1950, iniciou uma perseguição sem precedentes a supostos comunistas infiltrados em diversos campos de atuação com o objetivo de destruir os valores e tradições democráticas norte-americanas.

30 Disponível em: <https://brasil.elpais.com/brasil/2020-08-20/os-lacos-do-cla-bolsonaro-com-steve-bannon.html>. Acesso em: 08/07/2021.

31 Os trechos acima foram extraídos das páginas 5 e 48 do Programa de Governo do Partido Social Liberal (PSL), partido que abrigou a candidatura de Bolsonaro à Presidência da República em 2018. É importante frisar que, na segunda passagem, a uma
} 
midiáticos do marxismo cultural sobre o referido programa de governo. Neste ponto, em especial, é preciso notar que essas visões não só se encontram, mas também se reforçam, à medida que têm como denominador comum o ultraconservadorismo e, até mesmo em alguns casos, o reacionarismo. Em suma, não é demais reforçar, o marxismo cultural é entendido como uma estratégia de dominação das mentes e dos corações, sobretudo quando aplicada ao contexto escolar. Disso depreende-se as críticas aos educadores, especialmente os que adotam uma visão mais progressista em relação aos dilemas contemporâneos. Ao fim e ao cabo, mesmo a defesa do óbvio, como a igualdade de gênero, o respeito à orientação sexual, à diversidade cultural e a luta pela diminuição das desigualdades socioeconômicas, soa aos ouvidos moucos dos conservadores e reacionários como um ato de "doutrinação" marxista da pior espécie. É interessante notar que o recurso à generalização, que toma os professores como agentes movidos pela má-fé e cujo intuito seria ideologizar o espaço escolar, está presente em quase todos os discursos empreendidos pelos defensores destas pautas antimarxistas.

Sobre isso, cumpre fazer alguns questionamentos. Em que dados e fatos tais críticas se assentam? Qual a proporção de professores marxistas a usarem a sala de aula com vistas a difundir suas ideias políticas? Seriam os alunos completamente incapazes de retrucá-los? Como explicar a guinada à direita que, nos últimos anos, se processou no Brasil visto ser o marxismo cultural tão presente nas escolas? Esse proselitismo estaria restrito à esquerda?

Não há qualquer indício ou comprovação de que os professores ajam ideologicamente em sala de aula. Com isso não se está afirmando que não possa haver casos deste tipo, mas certamente são pontuais, e seus impactos certamente são diminutos. Obviamente, essas acusações carecem de provas e servem apenas como forma de delinear imageticamente um inimigo, responsável pelos males que acometem o país e que, por isso, deve ser combatido por aqueles que desejam uma nação verdadeiramente livre do controle marxista.

Olavo de Carvalho, que afirma ter sido comunista no passado remoto, simplesmente parece esquecer que a ideologia não é apenas um produto social, mas um elemento decisivo na luta de classes. Ele rejeita, portanto, o fato de que a classe ou fração de classe dominante visa sempre justificar sua dominação ao impô-la como representação mental às classes dominadas. Conforme Marx e Engels (2007, p.47) alertam numa passagem de A Ideologia Alemã:

A classe que tem à sua disposição os meios de produção material dispõe também dos meios da produção espiritual, de modo que a ela estão submetidos aproximadamente ao mesmo tempo os pensamentos daqueles aos quais faltam os meios da produção espiritual [...]. Os indivíduos que compõem a classe dominante [...] regulam a produção e a distribuição das ideias de seu tempo.

clara tentativa de aproximar Paulo Freire do marxismo, ou seja, com um dos arquitetos da ideologização dos conteúdos escolares cujo intuito é doutrinar os alunos no comunismo. Disponível em: <https://divulgacandcontas.tse.jus.br/candidaturas/oficial/2018/BR/BR/2022802018/280000614517/proposta_15342846 32231.pdf> Acesso em: 08/07/2018. 
No capitalismo, a classe ou fração de classe que domina os meios de produção e consequentemente a difusão de ideias e valores, não é o proletariado. Assim sendo, tanto o sistema escolar quanto os veículos de comunicação não estão diretamente disponíveis ao controle dos trabalhadores, visto que a burguesia detém esses instrumentos de dominação, seja por meio do Estado, seja por meio da influência exercida pelo capital, o que não significa que, ao se tonar uma "classe para si", isto é, uma classe autoconsciente da exploração à qual está submetida, estes não possam e não devam se organizar politicamente, mas também em termos representacionais e valorativos. É isso, certamente, o que mais assusta a burguesia e o seu sistema de dominação.

Não obstante, também seria de bom tom perguntar: o que é o marxismo cultural para a esquerda? Dialeticamente, para os marxistas, o marxismo cultural nada mais é do que a fusão dos trabalhos sobre o “marxismo ocidental”, de Perry Anderson, e do "materialismo cultural”, de Raymond Williams, além, é claro, dos trabalhos dos autores frankfurtianos já mencionados - Adorno, Horkheimer, Benjamim -, bem como os de Marx e Gramsci, ou seja, de todo um legado de crítica ao modo de produção capitalista, mais ou menos balizado pelo conceito marxista de "luta de classes" transposto ao campo cultural, além de sua crítica à ideologia dominante, que se volta contra todo e qualquer tido de opressão (COSTA, 2020). Neste sentido, os marxistas não têm do que se envergonhar, pois se enquadram no interior de uma tradição teórica que, desde sua origem, nunca escondeu seus objetivos, os motivos de sua luta e seus adversários políticos. De modo que, mesmo com os insistentes obituários, que volta e meia decretam sua morte, o marxismo resiste e, com um fantasma ou um defunto, movido por uma espécie de síndrome de Lázaro, ressurge para atestar sua resiliência, como bem observou Derrida (1994) na epígrafe do início deste texto. Afirmar-se marxista é, com efeito, assumir uma posição diante do mundo e reiterar uma história de refluxos e avanços de uma esquerda que jamais temeu dizer seu nome, desde Marx até outros tantos pósteros (SAFATLE, 2012). Afinal de contas, como destaca Hannah Arendt (2021), Marx inscreve-se no marco da tradição do pensamento político ocidental, embora adotando um viés herético em relação ao idealismo ainda presente em sua época, mas que, diferentemente do que alguns de seus críticos sugerem, não pode ser falsamente acusado pelas agruras dos governos totalitários socialistas que marcaram o século XX, visto que entre eles, a despeito de algumas aproximações, há diferenças substanciais quanto à concepção societária.

\section{CONSIDERAÇÕES FINAIS}

Como se procurou demonstrar ao longo deste artigo, as mídias (tradicional e alternativa) tiveram um papel fundamental nas análises acerca do marxismo nos últimos anos, sobretudo quando o Partido dos Trabalhadores, que não é majoritariamente marxista, chegou ao Governo Federal. Muitos articulistas e formadores de opinião procuram, não sem distorcer as ideias fulcrais de Marx, conciliar o suposto fracasso dos regimes socialistas às políticas empreendidas pelo primeiro governo de esquerda eleito na 
história brasileira. Sobretudo a interpretação olaviana segundo a qual o marxismo deslocou o seu foco de luta, passando do campo político para o campo cultural, reforçou a impressão de que a esquerda passou a adotar uma nova estratégia de tomada do poder. Esta interpretação fora fundamental para que os professores passassem a ser vistos como agentes conscientes e moralmente inclinados a utilizar a escola como um espaço de difusão dos valores e ideias marxistas. Não por acaso, a discussão sobre o "marxismo cultural" tornou-se proeminente nos últimos anos a ponto de um movimento, o Escola Sem Partido, ter surgido e tentado emplacar uma série de punições jurídicas ao suposto proselitismo político dos professores. Houve mesmo, por parte de alguns representantes deste movimento, o estímulo a alunos e pais de alunos no sentido de monitorar os professores em sala de aula com vistas a puni-los judicialmente. Alguns profissionais da educação, inclusive, foram convocados a depor ou até mesmo processados por, suspostamente, ideologizar suas aulas, aproveitando-se da imaturidade intelectual de seus alunos. Contudo, conforme nos propusemos a revelar, essas narrativas não só carecem de um conhecimento profundo do marxismo, mas não também de provas que validem o teor das acusações dirigidas a esses profissionais. Por isso mesmo trata-se de narrativas, sem base em comprovações e dados colhidos a partir do esforço sério e razoável do qual as ciências humanas estão imbuídas. Certamente, Marx denunciaria o viés ideológico incutido nessas narrativas. Foi o que bem ou mal tentamos realizar aqui.

\section{REFERÊNCIAS}

AQUINO, Rubim Leão. (Org.) Sociedade Brasileira: uma história através dos movimentos sociais. Rio de Janeiro: Record, 2007.

ARENDT, Hannah. "Karl Marx e a tradição do pensamento político ocidental” In: Pensar sem corrimão: compreender 1953-1975. Rio de Janeiro: Bazar do Tempo, 2021. p. 35-75.

CASTELLS, Manuel. Sociedade em Rede. Rio de Janeiro: Paz e Terra, 2013.

COSTA, Iná Camargo. Dialética do marxismo cultural. São Paulo: Expressão Popular, 2020.

DERRIDA, Jacques. Espectros de Marx. Rio de Janeiro: Relume-Dumará, 1994.

FAUSTO, Boris. História Geral do Brasil. São Paulo: Edusp, 2012.

GRESPAN, Jorge. Marx: uma introdução. São Paulo: Boitempo, 2021.

OLIVEIRA, Francisco. Crítica da Razãa Dualista: o ornitorrinco. São Paulo: Boitempo, 2003.

MAGALHÃES, Fernando. 10 lições sobre Marx. Rio de Janeiro: Cortez, 2017.

MARX, Karl; ENGELS, Friedrich. A Ideologia Alemã. São Paulo: Boitempo, 2007. . O Capital: crítica da economia política. Livro I. 2. ed. São Paulo: Boitempo, 2011. . O Manifesto do Partido Comunista. São Paulo: Boitempo, 2012.

NICOLAU, Jairo. O Brasil dobrou à direita: uma radiografia da eleição de Bolsonaro em 2018. Rio de Janeiro: Zahar, 2020. 
ROCHA, Camila; SOLANO, Esther. “A ascensão de Bolsonaro e as classes populares” In: AVRITZER, Leonardo; KERCHE, Fábio; MARONA, Marjore (Orgs.). Governo Bolsonaro: retrocesso democrático e degradação política. Belo Horizonte: Autêntica, 2021. p. 21-34.

ROCHA, João Cezar de Castro. Guerra cultural e a retórica do ódio: crônicas de um Brasil pós-político. Goiânia: Caminhos, 2021.

SAFATLE, Vladimir. A esquerda que não teme dižer seu nome. São Paulo: Três Estrelas, 2012.

SCHWARCZ, Lilia. Sobre o autoritarismo brasileiro. São Paulo: Companhia das Letras, 2019.

SCHWARCZ, Roberto. As ideias fora do lugar. São Paulo: Penguin Classics/Companhia das Letras, 2014.

27 SINGER, André. Os sentidos do lulismo. São Paulo: Companhia das Letras, 2012.

SOUZA, Jessé. A ralé brasileira: quem é e como vive. São Paulo: Contracorrente, 2009. . A elite do atraso: da escravidão à Lava Jato. São Paulo: Leya, 2017. 